\title{
Role of Government, Private and Cooperative Stakeholders in Development and promotion of Financial Products: A Study of Farmers Producers Organisations (FPOs)
}

\author{
Priti Sharma, Himani Upreti, Mohit Kumar Ojha, Shipra Gupta
}

\begin{abstract}
The study is an attempt to assess the role of Central and State Government and Co-operative Societies in promoting FPOs in Maharashtra, India. Study also explores Financial Products and their development in order to meet financial needs of FPOs. Finally, study provides measures for promotion and development of FPOs so as to make Agri Finance viable option even for poors'. Study follows descriptive research method based on secondary data and information collected from reports of government agencies, institutions and bodies. In order to ensure the quality and authenticity of results, only reliable websites of central and state government have been accessed. Initiatives have been taken at both Central and Stale level for promotion of FPOs and to develop financial products for financing FPOs. A lot has been done still a long way to go so as to make environment conducive for FPOs. Study concludes that FPOs play a positive role and leads to enhanced income for farmers by providing them with access to institutional credit, informed and better decisions, access to better and improved inputs, effectiveness \&efficiency in farming operations and better marketing facilities; there still remains challenges and policy gaps that are unaddressed. Few of the major challenges faced by institutions and government agencies in building strong and sustainable FPOs include inadequacies related to professional management, access to credit, risk mitigation mechanism, accessibility to market, alongside weak financials and lack of technical skill and awareness among users of FPOs.
\end{abstract}

Keywords: Central Government, State Government, Cooperative Societies, Financial Products, FPOs, Agri Finance.

\section{INTRODUCTION}

India is predominantly an agrigarian economy and depends heavily upon that; agriculture in India is more or less production oriented (NABARD, 2019). Agriculture sector in India is characterized by large number of fragmented small holdings by farmers. Agriculture accounts for almost 56 per cent of employment in the country and thereby contributes heavily towards growth and development of economy. With its employment generation capability, it promotes economic development by reducing poverty and assuring food security to this ever increasing population (NABARD, 2019).

Despite the importance of agriculture sector for Indian economy,

Revised Manuscript Received on October 02, 2019.

CA Priti Sharma, Assistant Professor, Graphic Era Deemed to be University, Dehradun, India.

Ms. Himani Upreti, Assistant Professor, Graphic Era Deemed to be University, Dehradun, India.

Dr. Mohit Kumar Ojha, Assistant Professor, Graphic Era Deemed to be University, Dehradun, India.

Shipra Gupta, Associate Professor, Department of Commerce, Graphic Era Hill University, Dehradun, India. it is plagued by certain pre-dominant factors like small farmers with fragmented, heterogeneous and scattered landholding, ever increasing cost of cultivation, marginal access of small farmers to resources and markets, and so on.

These challenges have left small holding based agriculture unviable. Further, the problems like limited access to quality inputs, lack of modern $\&$ advanced technologies, inability to avail cheaper credit \& finance, limited production quantity, crop failures, income security, unavailability of assured markets, poorly structured supply chain, and so on has led to pitiable situation where farmers have to heavily rely/depend upon intermediaries and local lenders who exploit them with high rates of lending and strict repaying norms (NABARD, 2019).

The condition is so worse that, around 85 per cent of total land holding is with small and marginal farmers; they hold only 44 per cent of cultivable land. Basic concerns of small farmers which are still unaddressed are; inability of technology adoption, low level of farming and extension options, limited capital at charge, low level of business skill, income insecurity and poor market efficiency.

The condition of small and marginal farmers demands for breakthrough in structural reforms and calls for transformational initiatives in order to revitalise Indian agriculture sector. Accepting the herculean task of revamping Indian agriculture sector, the Government of India had come up with plans where they are encouraging small and marginal farmers to undertake projects in selected areas. In such projects, certain portion of total project cost will be subsidized by the Government. Major objective of such projects will be to enhance capital investment, employment generation, income security and sustained level of income flow. Continuing with the process, both Central and State Government have promoted the concept of Farmers Producers Organizations (will be referred to as FPOs here after) and agencies have continually contributed towards formation and development of FPOs. "The projects are financed through resources of different centrally sponsored schemes along with various State-funded schemes. The goal of promoting and developing FPOs will be achieved successfully by involving partners from research organizations, civil society institutions, private bodies/players and various entities able to contribute towards development of FPOs"(www.sfacindia.com).

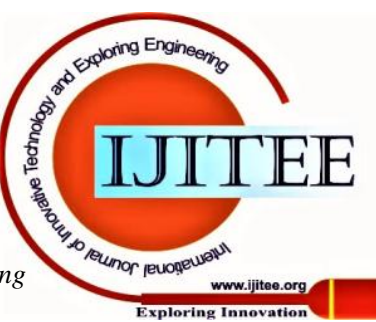


The main objective of FPO is to ensure better income for the producers through an organization of their own. Small producers do not have the volume individually (both inputs and produce) to get the benefit of economies of scale. Through aggregation, the primary producers can avail the benefit of economies of scale. They will also have better bargaining power vis-à-vis the bulk buyers of produce and bulk suppliers of inputs.

\section{PROBLEM STATEMENT AND PURPOSE}

The objective of the study is to assess the role of Central and State Government and Co-operative Societies in promoting FPOs in the State of Maharashtra, India. Study also explores Financial Products and their development in order to meet financial needs of FPOs. Finally, study provides measures for promotion and development of FPOs so as to make Agri Finance viable option even for poors'.

\section{THEORETICAL BACKGROUND}

Role of Ministry of Agriculture, Government of India for Support and Promotion of FPOs

Vision

"To build a prosperous and sustainable agriculture sector by promoting and supporting member-owned Producer Organizations, that enable farmers to enhance productivity through efficient, cost-effective and sustainable resource use and realize higher returns for their produce, through collective action supported by the government, and fruitful collaboration with academia, research agencies, civil society and the private sector" (Department of Agriculture Cooperation \& Farmers Welfare, 2013).

Mission

- “To promote economically viable, democratic, and self-governing Farmer Producer Organizations (FPOs)" (Department of Agriculture Cooperation \& Farmers Welfare, 2013).

- "To provide support for the promotion of such FPOs by qualified and experienced Resource Institutions (RIs)" (Department of Agriculture Cooperation \& Farmers Welfare, 2013).

- "To provide the required assistance and resources policy action, inputs, technical knowledge, financial resources, and infrastructure - to strengthen these FPOs" (Department of Agriculture Cooperation \& Farmers Welfare, 2013).

- "To remove hurdles in enabling farmers, access the markets through their FPOs, both as buyers and sellers" (Department of Agriculture Cooperation \& Farmers Welfare, 2013).

- "To create an enabling policy environment for investments in FPOs to leverage their collective production and marketing power" (Department of Agriculture Cooperation \& Farmers Welfare, 2013). Central Government by way of various institutions, have actively involved in the promotion and development of FPOs in India. Few landmark initiatives are:

- Department of Agriculture and Cooperation (DAC), Ministry of Agriculture, Govt. of India is designated as the nodal agency for the promotion and development of FPOs.

- A society body is formed under DAC named "Small Farmers' Agribusiness Consortium (SFAC)". It will act as a designated agency and single-window for research and knowledge management, fulfilling training needs, providing technical support and creating linkages between technology, investment\& markets.

- Central Government via DCA has extended the mandate of National Cooperative Development Corporation (NCDC) so as to make FPOs eligible to be included in the list of institutions receiving financial and technical support under one or the other schemes/programmes of NCDC and Central Government.

- "NAFED will take steps to include FPOs in the list of eligible institutions which act on its behalf to undertake price support purchase operations" (Department of Agriculture Cooperation \& Farmers Welfare, 2013).

- DAC will work in collaboration with Food Corporation of India (FCI) and other State Governments in order to make FPOs eligible to be included as procurement agencies.

- In order to fulfil investment needs of FPOs, Government of India has allowed DAC to collaborate with NABARD and other financial institutions. They will provide FPOs with short/medium term credit to finance their working capital and infrastructure investment needs.

- In association with relevant stakeholders, DAC will strive to achieve 100 per cent financial inclusion of FPOs members by linking them to KCC (Kisan Credit Cards).

Role of Central Government Institutions in Promoting FPOs

\section{Important Measures initiated by NABARD}

Since its inception in 1982, NABARD has continuously worked towards agriculture financing and has achieved various feet over the course of their illustrious journey of 37 years. It has launched various schemes and programmes for promotion, formation and development of FPOs. In the years 1997, NABARD has created an own subsidiary called NABKISAN Finance Limited for specifically fulfilling financial needs and credit requirements of FPOs. Further, in the year 2012, NABARD has created a fund called "Producers Organization Development Fund (PODF)" to support FPOs in their financing needs; the scheme also included PACS so as to develop an innovative financing model. The fund was first created in 2012 out of NABARD's operating surplus with an initial investment of INR 50 crore. Overwhelmed with the success of PODF scheme which facilitated affordable credit, enhanced access to inputs, skill development and competitive price realization for FPOs and PACS, the scope has been enhanced in 2017-18 to bring FPOs into purview which are previously financed by Commercial Banks, Regional Rural Banks and Co-operative Banks (NABARD, 2019).

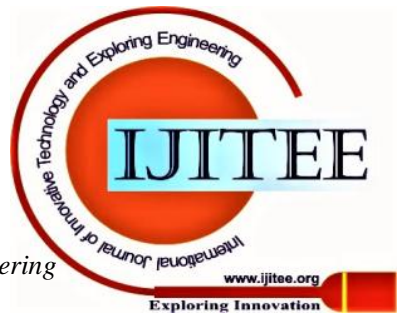


Some major initiatives by NABARD are discussed below:

- A National Advisory Committee has been created by NABARD to oversee the promotional efforts of various agencies and to suggest inputs for facilitation and creation of conducive ecosystem and environment in which FPOs will sustain and thrive in their operations. The committee will be headed by the Chairman of NABARD and will include members from different Ministries of Government of India, academic institutions, SFAC, corporate from Agri sector, members from professional agencies and members of some leading FPOs.

- On the same lines, NABARD has formed various State Level Consultative Committees under its Regional Offices. The role of State Level Consultative Committee will be providing advisory services and to frame guidelines for successful implementation of different schemes. The committee will strive to achieve synergy between efforts of stakeholders for creation and development of strong and sustainable FPO.

- In order to address the need for a centralized data base and management system, NABARD has launched a web portal which is dedicated for FPOs. All the data related to FPOs including detailed profiles of shareholder members of respective FPOs will be digitized in the web portal and will be made available for use by stakeholders.

- NABARD has also initiated actions towards measuring performance of FPOs and in this direction they have constructed a "Performance Management (grading) Tool" which will assess and

- NABARD in collaboration with SEBI and Commodity Exchanges has organized a National Level Seminar on "Linking Farmer Producers' Organizations with Commodity Exchanges". The objective of the seminar was to enhance farmers' participation on trading platforms and suitable road map for the same had been suggested in the

- In continuation of the above seminar, training programmes has been conducted at state/district level of the benefit of small and marginal farmers.

- Various loans and finance products has been developed and introduced by NABKISAN Finance Ltd. for providing financial support to FPOs. Digital Platforms has also been created to promote on-line application submission so as to make the loan process easy and time effective.

- NABARD has also launched a Credit Guarantee Scheme so as to cover risk of its subsidiaries emanating from lending to FPOs.

\section{Schemes of Government of India/SFAC for FPOs}

"The Union Finance Minister, in the Budget Speech for 2013-14, announced two major initiatives to support Farmer Producer Companies (FPCs) viz., support to the equity base of FPCs by providing matching equity grants and Credit Guarantee support for facilitating collateral free lending to monitor the functioning and performance of FPOs. seminar.

FPCs" (NABARD, 2019). Various initiatives by Government and SFAC are:

\section{- Equity Grant Fund Scheme}

The main objectives of the scheme were to enhance viability and sustainability of FPCs, increase their credit worthiness and to enhance the shareholding of members so as to increase their ownership and participation. The maximum limit of grant will be INR 10 lakh per FPC provided the minimum shareholder membership be 50 farmers.

\section{- Credit Guarantee Fund Scheme}

The scheme is launched to provide Credit Guarantee Cover to eligible lending institutions so that they can fund collateral free credit to FPCs. The scheme is applicable only for loans up to INR 100.00 lakhs. Only those Farmer Producer Companies are covered under the schemes which have minimum 500 individual shareholders.

- Scheme for Creation of Backward and Forward Linkages

"The Ministry of Food Processing Industries, Government of India has come up with a scheme to allow effective, efficient and seamless way of backward and forward linkages by bridging the gaps in the supply chain. The scheme provides financial support to set up primary processing/collection centres at farm gate level and modern and equipped retail outlets at the front end level. It will also provide support for setting up insulated/refrigerated transport connectivity. Perishable horticulture and non-horticulture produce such as vegetables, meat, fruits, dairy products, fish, poultry, mushroom, coconut, honey, spices, ready to cook food products and retails shops for perishable food products are covered under this scheme" (NABARD, 2019).

- National Rural Livelihood Mission (NLRM) Under the flagship programme of Deendayal AntyodayaYojana-NRLM, Ministry of Rural Development, Government of India has initiated to bring interventions for building of developed value chains. The primary focus of these interventions will be sustainable agriculture and livestock development so as to makes mall and marginal farmers able to access markets, gain better prices, create value addition, access improved technologies and gain modern and advanced technical support. As a result of this initiative, many producers' groups are promoted and gradually transformed into member-owned, member-governed and sustainable Producers' Enterprises (PEs).

Role of State Government Institutions in Supporting FPOs

DAC has suggested following steps to be taken by State Governments to promote, support and strengthen FPOs (Department of Agriculture Cooperation \& Farmers Welfare, 2013): 
- State government will declare FPOs at par with cooperative societies which are registered under the applicable State legislation and self-help groups/federations in order to allow them for all the facilities and benefits extended to other memberowned institutions.

- State Government will make provisions for easy norms of license issues to FPOs.

- State Government should amend APMC Act so as to allow FPOs to sale farm produce directly at farm gate. The direct sale process will be facilitated through FPO owned procurement and marketing centres.

- State Government should appoint FPOs as procurement agents for MSP operations for various crops.

- FPOs to be linked with different financial institutions with the likes of State Financial Corporations, Cooperative Banks, and so on so as to make it easy for FPOs to finance their working capital and infrastructure related investment needs.

- State Government need to promulgate policies at state level so as to make FPOs sustainable, vibrant and self-governing bodies.

Role of Resource Institutions (RIs) In Developing FPOs:

- RIs Working in the Area and FPOs they Handle:

\section{ANALYSIS OF DATA}

\section{Management of FPOs}

- Management Structure

\section{Institutional Model}

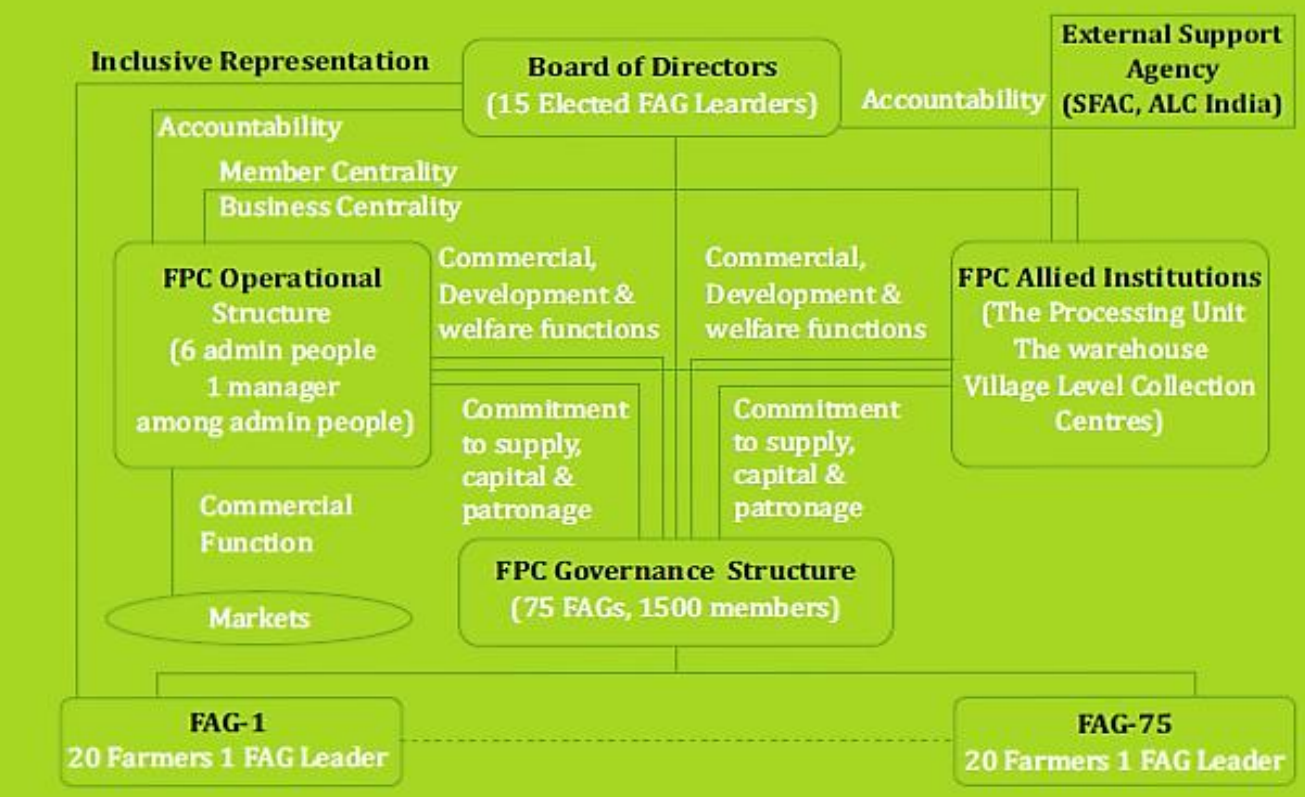

Figure 1: Management Structure of an FPO

(Source: Access Livelihoods Consulting Group's Report) 
- Business Plan

A Business Plan must include the following

○ Project Profile/ Snapshot

The purpose of the business plan, location, resource requirements, volume of business, a brief note on market/

- Promoter/ Entrepreneur Profile

Director's qualification, training and experience relevant to the project

o Details of the Proposed Project

Requirement of project cost and working capital and means of finance

- Market Potential

Brief on potential customers, competition and marketing strategy

- Manufacturing Process

Description of the manufacturing process, plant capacity, expansion plans, quality control procedures etc.

○ Income Statement

Plant Capacity, capacity utilisation, quantity produced/sold and sales realization

- Expenditure Statement

Cost of raw materials, utilities, manpower, repairs and maintenance, selling and distribution expenses, administrative expenses, interest on loans availed, depreciation and any other expenses

- Profitability Projections

Sales, cost of manufacturing, tax liabilities, repayments, retained profit/loss

- A business plan may be as rigorous as an entrepreneur wants. The greater the rigour, the greater the potential for successful expansion and growth

\section{- Hierarchy}

\section{STRUCTURE OF FPO}

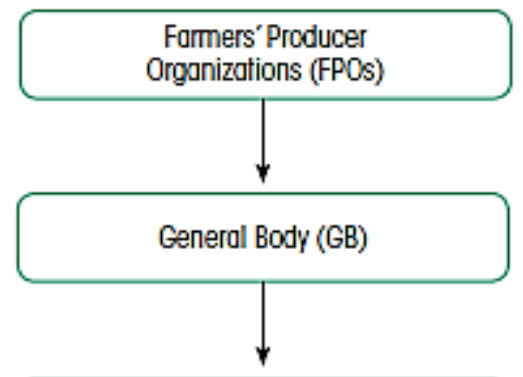

Executive Body

(2 Representatives per FIG)

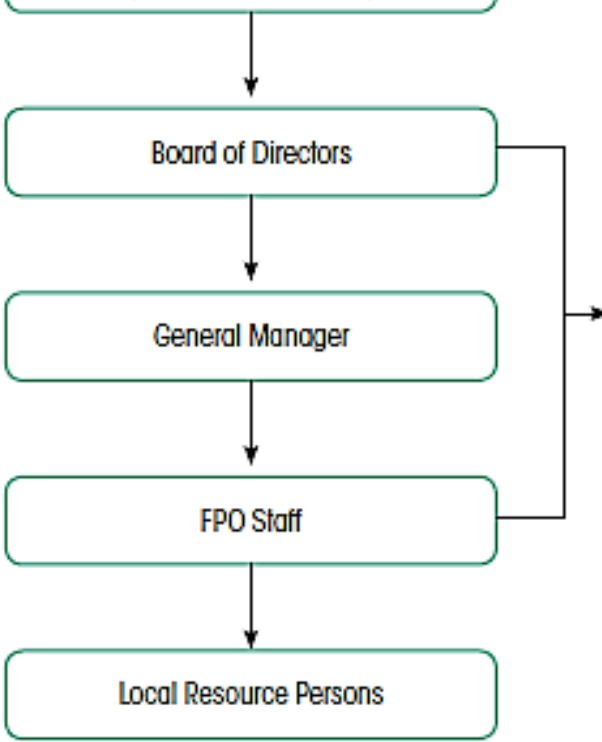

\section{STRUGTURE OF FPO}

1. Input Supply

2. Financial

3. Technical

4. Insurance

5. Procurement

6. Packoging

7. Marketing

8. Networking
1. Planning

2. Implementation

3. Monitoring

Figure 2: Management Hierarchy of FPO

- Management of Day to Day Operations

To run their daily business activities FPOs have some key personnel (Manager/ Director/ CEO) as well as some workers appointed, in consideration they get paid (remuneration/salary)

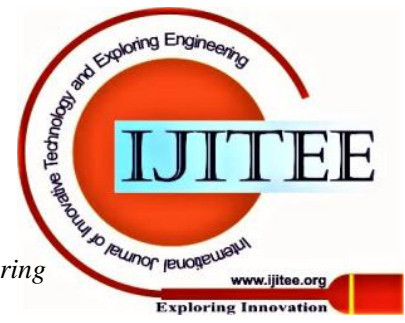


Role of Government, Private and Cooperative Stakeholders in Development and promotion of Financial Products: A Study of Farmers Producers Organisations (FPOs)

- Segmentation of FPOs

\section{○ Geographical Segmentation}

This includes all FPOs registered under all government agencies and institution in Maharashtra.

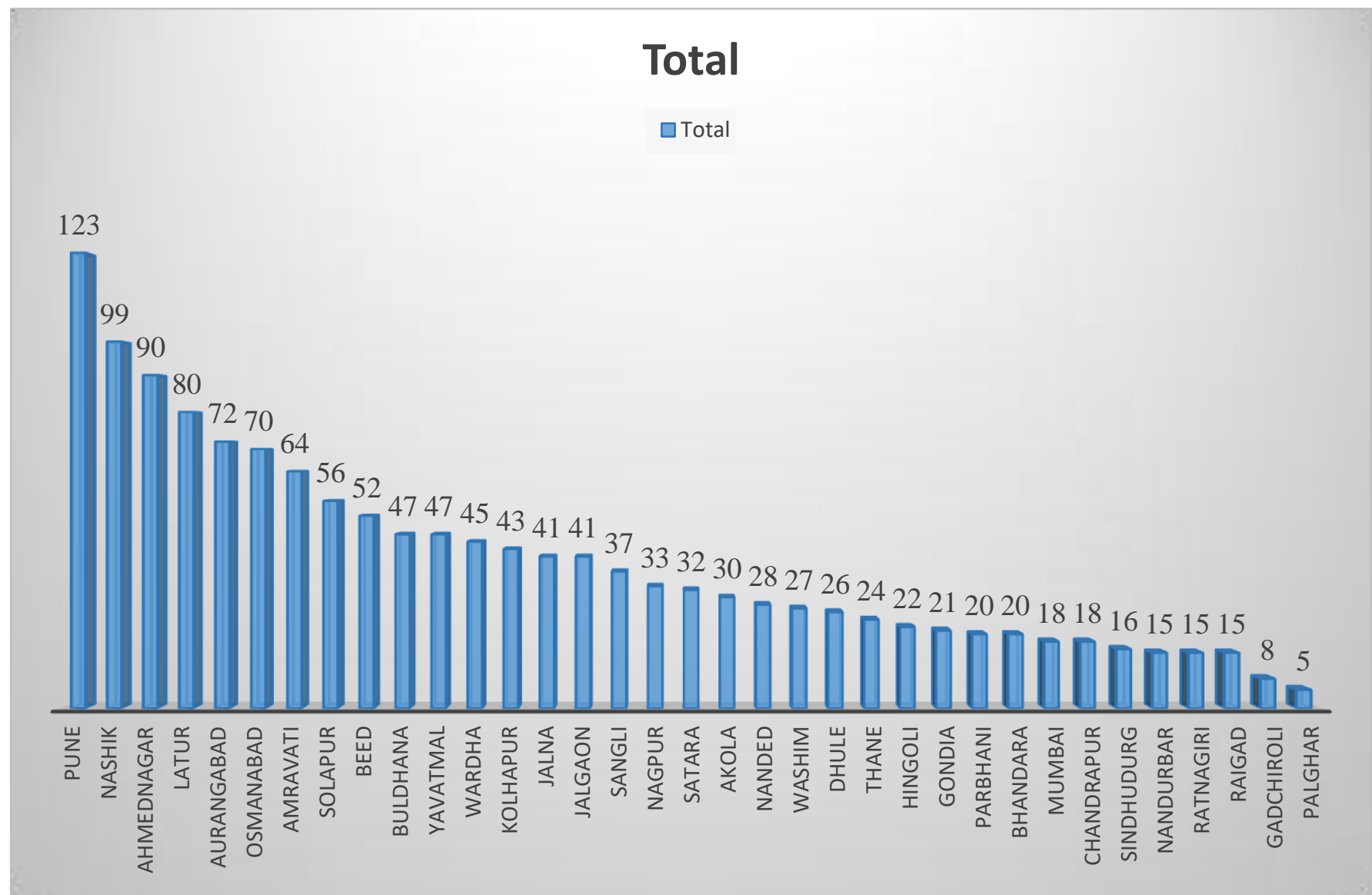

Figure 3: District Wise Number of Registered FPOs

(Source: Krishi Maharashtra website, up to 31-12-2017)

Segmentation by Area of Operation

This includes all FPOs registered in the State of Maharashtra under SFAC only

\section{Segmentation by Area of Operation}

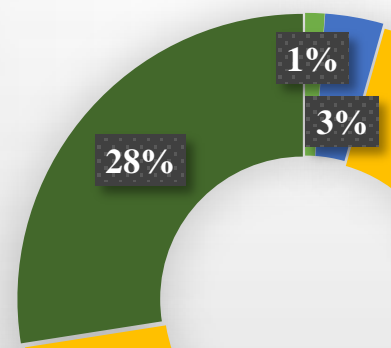

Figure 4: Segmenting FPOs by Area of Operation

(Source: www.sfacindia.com)

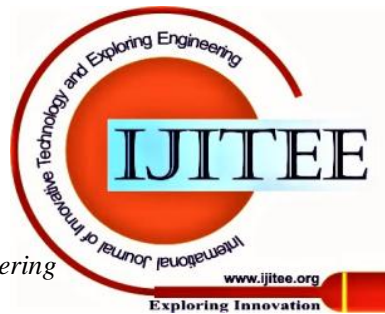


- Segmentation based on SFAC Programmes

This includes all FPOs registered in the State of Maharashtra under SFAC only

\section{SEGMENTATION BASED ON SFAC PROGRAMMES}

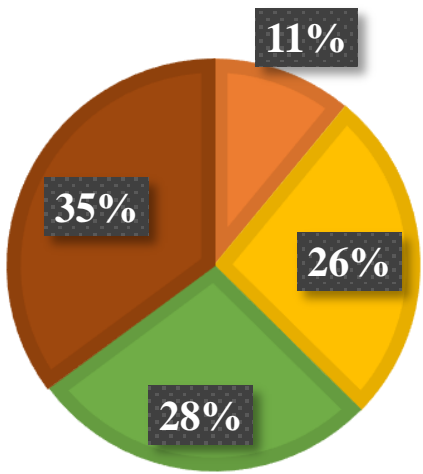

- National Demonstration Project -NFSM

- Pulses Programme

- Tribal Development Department (TDD)

- Vegetable Initiative for Urban Cluster (VIUC)

Figure 5: Segmenting FPOs on Basis of SFAC Programmes

(Source: www.sfacindia.com)

Segmentation based on Year of Registration

This includes all FPOs registered in the State of Maharashtra under SFAC only

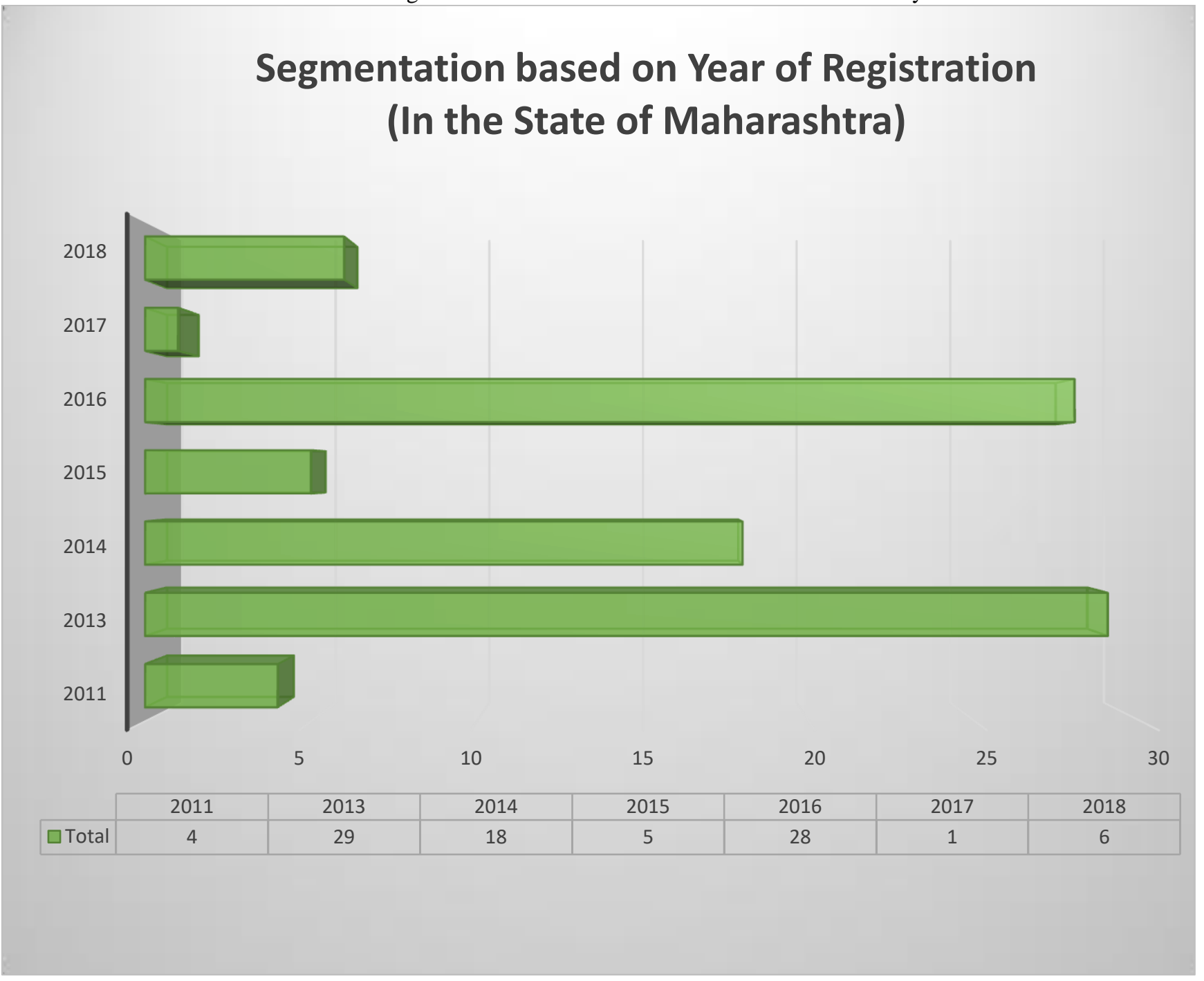

Figure 6: Segmenting FPOs by Year of Registration

(Source: www.sfacindia.com)

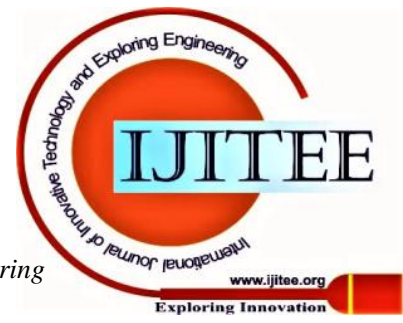


- Segmentation based on Resource Institutions (RIs)

This includes all FPOs registered in the State of Maharashtra under SFAC only

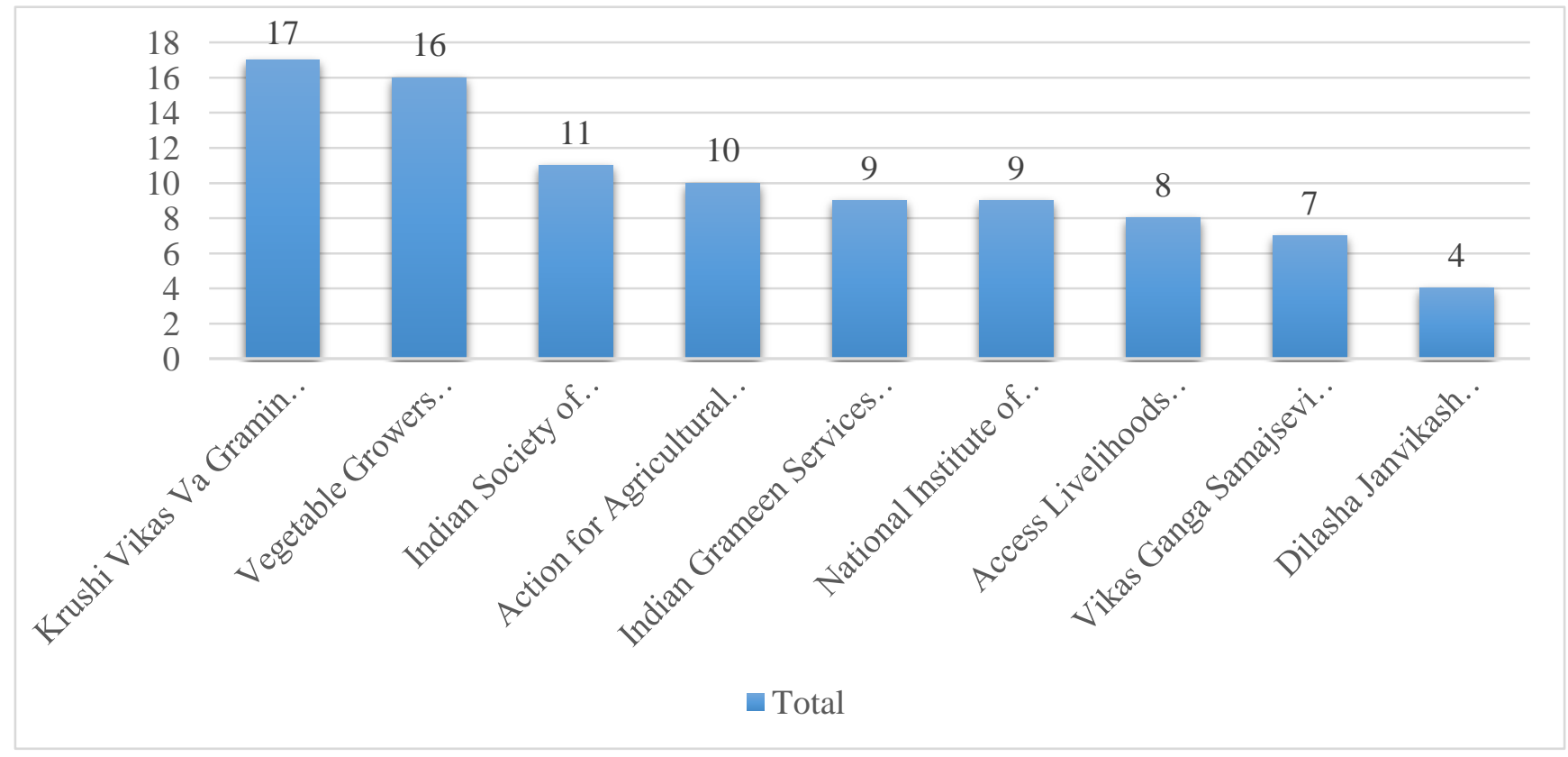

Figure 7: Segmenting FPOs Based on Resource Institutions

(Source: www.sfacindia.com)

- $\quad$ Financing Requirements of FPOs

- Working Capital Requirements

The working capital requirements of FPOs emanates from their expenditures on maintenance machines, up keeping of equipment, rent, salary and other such expenses of operational nature. On an average, the working capital requirement for an FPO comes out to be INR 3 Lakhs.

- Financing Required for Capital Expenditure

FPO members require funding to finance their equipment and machineries. Few get financial support from FPO but not in every case. Usually members avail vehicle loan for mobility purpose to transport produce to market. Hence, FPOs working on processing model or planning to, will need financial support for business expansion and purchase of equipment and machineries.

- Suitable Products as per their Requirements

The suitable form of financial product for FPO can be short term unsecured loan because in case of secured loans, directors and members of FPO will have to put their personal assets as collateral. Hence in this regard, the optimum financing support would be to extend unsecured loans to them.

\section{Registration Process of FPOs}

Most preferred forms for FPO registration are FPCs and Cooperative societies. Their registration processes are as follows:

- Registration process of an FPC

A FPC can be registered as a body corporate under Section 465 of Companies (Amendment) Act, 2013. In such registrations, only primary producers can be the members of the FPC. The Time duration would be 2-6 months 39,600. A minimum 10 producers are required to form an FPC.
The legal formalities to be fulfilled are:

- Obtain digital signature of nominated directors

- Choose 4 names max (Form INC 1 Rs. 1000)

- Name acceptance letter from ROC

- Thereafter documents to be submitted to ROC:

- Articles of Association

- Memorandum of Association

- Form INC 22 for Reg. Office address

- DIR 12 for Director's Appointment

- DIN application

- INC 7 for affidavits by subscribers who have signed in Hindi

- Power of attorney to professional to make changes in MoA and AoA

- Certificate of Incorporation in Form INC 21

- Min 5 Directors and Max 15

- Registration process of an FPO as Co-operative Society

If a Co-operative society has to be registered at individual state than it has to get registered under Co-operative Societies Act; while if one has to get registered at central level, it need to be registered under Multi State Co-operative Society Act.

Legal formalities to be fulfilled:

○ At least 10 members above 18 years

- All members should be from same town, village

- If limited liability, then last word in name have "Limited" word with it 
Restrictions on Loans

- Can give loans to members

- Cannot lend on security of movable property without sanction of registrar

Dissolution

- On request of $75 \%$ members

- Within 2-month, appeal can be done to state govt. or revenue authority of state govt. against dissolution request

\section{RESULTS AND DISCUSSION}

As evident from the data provided above, it can be said that number of FPOs are ever increasing and it has helped small farmers in many ways. The new concept of FPOs is really a great success in some parts of Maharashtra but on the other side it failed because of many reasons which has been discussed later on. The successful FPOs are growing day by day because of the resources and support they are getting from the government agencies, financial institutions, NGOs and Resource institutions, while those unable to get get any such support were in a dire state where they couldn't be able operate and consequently had to shut down. Some FPOs were not able to comply with the legal requirements, reason being; lack of education, unawareness, political issues and thuswere barely able to operate.

All they need is initial handholding till the time they become independent and start operating and functioning smoothly. From the future perspective, the idea of the grouping up and working together to minimize risk and wastage of resources is really a viable option.

\section{IMPLICATIONS}

\section{Implications for funding agencies}

- Preliminary Farm Finance Programme

It will be helpful and beneficial to prepare new small holder finance programmes as it would require less time and will provide easy access to finance.

- Define Innovative Roles for Producer Organisations (POs)

Producer organizations need to be strengthened so as to make them perform their roles of marketing and linking activities in more effective and efficient ways. Towards this end, Investors role becomes important and they should provide them with capacity-building programmes.

- Provision of New Roles for Partner Financiers There are many challenges in front of financiers of small land holding farmers. In the context and to take up the challenge of easing out financing activities, Investors and other financiers should enable financial institutions to build staff expertise, develop new and innovative financial products, streamlining and improving due diligence process so as to allow for overall management of agri financing risks. The agricultural financing risk can be mitigated in different ways like, partner financial institutions may be stimulated by investors and social lenders so as to make them capable of understanding agri finance risk in a more comprehensive manner. Further, financial institutions can be coached by investors and social lenders with respect to asset-based lending; selfliquidating loans can be developed which should be backed up by stocks in tripartite agreement.

- Combination of Micro- and Agri-finance (Hybrid Financing Scheme)

In order to provide effective financing scheme, departments of micro-finance and agri-business finance need to collaborate because there is need for both pre and post harvest smallholder finance. In this regard, there is need to develop hybrid finance schemes which will generate new avenues for identification of partner institution.

- Options of Blended Funding and Investment

Though, most of the coaching of farmers are mobilised with the supply chain, there are still certain tasks for service providers and professional facilitators. For this, there is requirement of initial grant investments and wise blend of grant financing and debt financing may work out for smallholder farmers.

Initiatives have been taken at both Central and Stale level for promotion of FPOs and to develop financial products for financing FPOs. A lot has been done still a long way to go so as to make environment conducive for FPOs. Various challenges are there.

\section{Challenges and Issues in Building Robust FPOs}

Studies of NABARD has shown that FPOs play a positive role and leads to enhanced income for farmers by providing them with access to institutional credit, informed and better decisions, access to better and improved inputs, effectiveness \&efficiency in farming operations and better marketing facilities; there still remains challenges and policy gaps that are unaddressed. Few of the major challenges faced by institutions and government agencies in building strong and sustainable FPOs, are as under:

\section{- Inadequate Professional Management}

In order to make FPOs, effective and efficient, there is dire need to manage such FPOs by qualified and professional managers who are trained in such manner. Though the number of FPOs are ever increasing, very few are run and managed by professionals and there is huge scarcity of qualified, trained and professional manpower in rural areas to manage FPOs.

- Weak Financials

Most of the FPOs are comprised of small farmers or marginal farmers and ence the financial health of the FPO remain questionable specially in the initial phases of the formation.

- Inadequate Access to credit

As discussed in the previous point, small/marginal farmers form most of the FPOs and hence the poor financial health of FPO makes it even more troublesome for FPOs to avail affordable credit as those require collaterals and credit history of members/FPOs. 
Though there are schemes where by guarantee cover are provided by SFAC for collateral free loans but those are available only to those Producer Companies who have minimum of 500 shareholder members; most of the FPOs land up on the other side if the scheme either because of lack of enough members or because of poor financial health and this acts as a major challenge in front of FPOs.

- Inadequate Mechanism for Risk Mitigation

In the present scenario, there is no provision to cover business risk of FPO. Though, the risk associated with production at farmers' level is covered to some extent either by some insurance plans or through other crop or livestock cover schemes but none such facility is available for FPOs to cover their business related risk.

- Lack of Access to Market

To make an FPO strong and succeed in the future, it is must to promote and allow them to market their produce at competitive and remunerative price. In current scenario, this stands as a major issue in front of FPOs. Hence, there is need more opportunities for FPOs to identify local market needs and consumer preferences so that they can pull off some tie-ups with markets for sale of its produce. Further, there has to be provision for FPOs whereby they can make linkages with retailers, market players and industry in order to achieve long term sustainability.

- Lack of technical Skills/ Awareness

Most of the FPOs suffer from lack of technical expertise as the members are not well-versed with modern equipment, tools and techniques. Further they lack awareness of acts and regulations associated with formation of FPOs, its legal requirements, technical details and other compliances thereafter.

\section{CONCLUSION}

The study is based on the data with respect to promotion and development initiatives of Central and State Governments and Co-operative societies in the State of Maharashtra only; different assessment and result could be found if other states are also included or study being conducted pan India. Further, the study is solely based on secondary data; authors welcome future studies incorporating primary data in the form of perception and attitude of different stakeholders in the development and promotion of financial products in India. Present study sets up the preliminary ground work by investigating into the current practices towards Financial Product development; future studies can use it to advance further and dig deeper into the avenue by using advanced analytical tools and techniques.

\section{REFERENCES}

Reports

1. NABARD (2018). National Paper - PLP 2019-20. NABARD. Accessed from

https://www.NABARD.org/auth/writereaddata/CareerNotices/2708183 505Paper\%20on\%20FPOs\%20-\%20Status\%20\&\%20\%20Issues.pdf.
2. NABARD (2018). National Paper - PLP 2019-20. NABARD. Accessed from

https://www.NABARD.org/auth/writereaddata/CareerNotices/2708183 550Policy\%20Initiatives\%20-\%20NABARD.pdf

3. Department of Agriculture Cooperation \& Farmers Welfare (2013) Policy \& Process Guidelines for Farmer Producer Organisations, Ministry of Agriculture, Government of India. Accessed from http://sfacindia.com/UploadFile/Statistics/Farmer\%20Producer\%20Org anizations\%20Scheme.pdf.

4. Krishi Maharashtra (2017). District Wise List of Farmer Producer Companies Registered in Maharashtra State up to December. Accessed from

http://krishi.maharashtra.gov.in/Site/Upload/Pdf/FPC\%20Data\%20Upd ated\%20upto\%2031-12-2017.pdf

Websites

5. www.NABARD.org

6. www.sfacindia.com

7. www.rbi.org

8. krishi.maharashtra.gov.in 